\title{
The Beauty of the Sumberawan Folklore in the Village of Toyomarto Indonesia as Tourism Branding
}

\author{
Femi Eka Rahmawati ${ }^{1}$, Sony Sukmawan ${ }^{2}$, Fitrahayunitisna ${ }^{3}$ \\ \{femi_eka@ub.ac.id'1 , sony_sukmawan@ub.ac.id², fitra_3006@ub.ac.id ${ }^{3}$ \} \\ Universitas Brawijaya, Indonesia ${ }^{1,2,3}$
}

\begin{abstract}
Indonesia has a lot of folklore, including in the village of Toyomarto. Folklore can become oral history in a local society because it is able to record events that occurred in the past. Through folklore, this history is communicated from one generation to another. Over time, the function of folklore has also changed. However, the spirit in folklore can still be revived in various ways. The beauty of folklore and the beauty of the local community in communicating the memories of the times can be transformed into other media according to the demand of times. This transformation can be used as a tourism branding strategy. Toyomarto Village has a potential to become a natural as well as cultural tourism destination. The focus of the discussion in this article is (1) folklore in Toyomarto Village related to Sumberawan water sources and (2) folklore-based tourism branding. The results showed a wide variety of folklore variations that can complement previous research. The beauty of the folklore narrative can be used for tourism branding.
\end{abstract}

Keywords: Culture, Folklore, Tourism Branding

\section{Introduction}

Indonesia has countless cultural wealth in the form of folklore. This is a green field for research, considering many Indonesian oral traditions are still undocumented. Research is one way to record and document traces of oral traditions. Folklore can also be said to be oral history because its existence is sometimes believed by local people as the truth from the past [1].

The beauty of folklore is a characteristic of a local community. Folklore becomes an attraction to local people because the traditions and culture they have are different from other regions. This is a character and uniqueness in itself. Therefore, folklore can become the trademark of a region.

According to Danandjaja [2] folklore is divided into three, namely (1) oral, (2) semi oral, and (3) non-verbal. When research examines folklore, this means that it only includes oral and semi oral folklore. For example, oral folklore is folk language, traditional expressions (proverbs, words of wisdom, sayings), traditional statements (such as puzzles), folk poetry (pantun, verse, etc.), folk tales (myths, legends, fairy tales). Meanwhile, semi oral folklore, for example, is popular belief (superstitious matters), folk games, folk theater, folk dance, customs, ceremonies, folk parties and so on which have mixed elements between oral and non-verbal. For this reason, this study will discuss findings related to oral folklores about Sumberawan water sources in Toyomarto Village.

Folklore, as a part of society, has various uses. The uses of folklore in society include, among others, a medium for education, a means of entertainment or solace, social protests and 
a reflection of people's latent desires [2]. Meanwhile, according to Hutomo [3] folklore in society functions as: (1) as a projection system, (2) cultural validation, (3) social control or control of social norms, (4) children's educational tools, (5) providing a way on the justification of society not to be superior, (6) and a means of protesting injustice.

Endraswara [4] formulates the characteristics of folklore based on various views from Dundes, Thoms, Utley, Dananjaya to Hutomo. The characteristics of these folklore include: (1) spread orally, (2) has a prominent traditional value, (3) varies in each region, (4) it is unclear who created it from the beginning, (5) has a fixed formula, (6) has a use in society (community), (7) is sometimes prelogical (irrational), (8) is the common possession and joint responsibility of a community, (9) is innocent and spontaneous, and (10) some have an element of humor and advice.

The existence of folklore in Indonesia is in decline. However, as long as the character of Indonesian society is still a communal society, the folklore will continue to live even though it undergoes a change of form; oral fairy tales that were previously told by storytellers are now turned into stories in fairy tale books to be read. The development from oral to text has changed that. However, the current era is no longer just the era of oral or text alone, the world has changed in the era of secondary orality [5], namely the delivery of information and messages back to the oral part through audio-visual with new media, namely electronic and digital.

Sumberawan is a spring located in Toyomarto Village, Singasari District, Malang Regency, East Java, Indonesia. The people of Toyomarto Village have various interpretations of folklore related to Sumberawan water source. This is because people believe that Sumberawan water is a holy spring and has many miracles.

The community believes that the water that comes out of Sumberawan originates from Mount Arjuno and at the same time is the forerunner to the name Toyomarto Village which is etymologically taken from the words "Toyo" and "Marto". In Javanese, Toyo means water and Marto/Amarta means life, so it can be interpreted that Toyomarto means living water. Sumberawan spring is a spring that is believed to be a sacred place because it used to be a pilgrimage place for Prabu Hayam Wuruk and is believed to be the producer of Amerta Water (living water) in Kasurangganan (Gardens of Angels). The establishment of Buddhist stupas, which are later commonly referred to as the Sumberawan Temple, also support the practice of venerating this water source. The water that flows from Sumberawan is believed to function as a medium for medicine and beauty.

The development of technology which has influenced the life style and modern way of thinking has shifted people's belief in the mystical logic regarding the springs in Toyota Village, especially the Sumberawan spring. This also reduces the sacredness of the spring conservation ritual. The reduction in spring water flow must receive serious handling from the government. Regional autonomy must be optimally utilized to develop the biological potential of the Sumberawan spring and the cultural richness of the local community. This potential is believed to be able to support Sumberawan Springs as a tourist attraction through tourism branding as a form of village development that is more advanced, more independent, and more prosperous.

The focus of the problems discussed in this article are (1) folklore in Toyomarto Village related to Sumberawan Springs and (2) focus-based tourism branding. In this way, it is hoped that this discussion will be of use to the local government in cultural tourism branding. In addition, this discussion can utilize the existing folklore to become a cultural tourism commodity. Thus, findings from this research can provide a reference for village development, especially sustainable tourism development. 


\section{Method}

This study used a qualitative approach that is based on interaction with human behavior in certain situations according to the views of the researchers themselves. This approach was applied because it seeks to describe a phenomenon as it occurs naturally. The qualitative approach is of the view that in a community system there is an orderly bond, in this case the use, management, and conservation of the springs of the Toyomarto community.

This research was conducted in Toyomarto Village, Singasari District, Malang Regency. The data of this research were in the form of folkloristic expressions containing folklore related to Sumberawan springs. The research data in question originated from informants, including village elders, local residents, and village officials with the following criteria: (i) indigenous people permanently domiciled in Toyomarto Village and have knowledge of folklore; (ii) understand the aims and objectives of the researcher; (iii) have no speech and hearing problems; (iv) have extensive knowledge of language and culture, making it easy to tell stories. There were 30 informants with those criteria.

This research data collection used interview and observation techniques. Interview techniques were used to record data obtained from informants. Interviews were conducted in a free format (casual conversations). In order to produce clearer data, field notes were also used as important references. The observation technique used was participant observation, so that researchers collect data by observing as well as being directly involved with activities in the community. The observation technique was carried out as a complement to the interview technique.

\section{Results and Discussion}

\subsection{Sumberawan Folklore}

The rewriting of folklore focused on the power of Sumberawan springs. This is done with the hope of being able to contribute to the preservation of nature and the progress of culture. The formulation of village tourism branding based on water resources and folklore is aimed to advance the image of Toyomarto Village as a cultural heritage-based tourism destination. This is necessary to increase the popularity of Toyomarto Village and in turn increase village income. Ultimately, these efforts will add economic value to the welfare of the local community.

According to the book Dictionary of Anthropology, folklore is the common orally transmitted traditions, myths, festivals, songs, superstition and of all peoples. Folklore has come to mean all kind of oral artistic expression, and may be found in societies. Originally folklore was the study of the curiosities [6].

Folklore includes fairy tales, stories, saga, heroics, customs, songs of ordinances, literature, arts and regional clothing. Each of them belongs to the traditional community collectively. The development of folklore prioritizes the oral route. From time to time are innovative or rarely change. Because folklore is anonymous, no individual or individual has the right to monopolize ownership rights. Every member of the community is allowed to feel ownership and develop according to local conditions. It can be said that folklore is preserved by the supporting community voluntarily and with enthusiasm without coercion. In many places, folklore functions as a form of social solidarity. Sometimes the implementation of folklore is related to mystical rituals. The goal is to find peace in life. 
According to Sartono in Purwadi [7], in Javanese civilization there are two subcultures that are easy to distinguish: state culture and village culture. According to the Javanese, state is mawa tata, village is mawa cara. The meaning is state uses formal legal rules, villages use traditional customary rules. The state, in the Kejawen term, refers to the territory of the city. The main supporter of urban civilization is the monarchy (keraton). The palace culture is published through chronicles or historical stories. The rural tradition is in the form of fairy tales, parikan (quick poetry), and oral speech as a means of disseminating it. From a phenomenological point of view, both chronicle literature and folklore are constructs in the realm of thought, essential differences. Basically, chronicles are written documentation, whereas folklore includes a means of oral communication.

In its development over the centuries, Javanese culture has experienced a mutually influencing process between the two subcultures. Javanese folklore is actually a product of the acculturation process between various elements. Among other things, due to the influence of Hinduism, Buddhism and Islam, an acculturation of culture was formed. This process is very beneficial for the formation of local identities. Historical monuments in an area are indicators of historicity and show their cultural units. Likewise, the benefits of folklore as a folklore monument, in fact, show cultural identity. Folklore displays the character or style of regional culture. The historicity of the area is invested and thus its character or identity, the cultural historical dimension in the area is expressed, then through folklore the character of the area will be apparent.

The results of the study were obtained from informants Mbah Rusno (local elder), the ground keeper Pak Kasun, and community members. The results showed that the construction of folklore narratives in Toyomarto Village related to Sumberawan Springs consisted of legends, myths, folk beliefs, folk tales, and traditional ceremonies.

The legends found consisted of (a) the origin of the name Sumberawan, (b) the origins of Toyomarto Village and Tirtoyudo District, and (c) the origin of the Tlatah Kesatrian. The myths that have been discovered include (a) the holy hermitage (b) the lake of nymphs, and (c) the myth of the dragon sword. The people's beliefs that were found consisted of (a) the properties of holy water (b) the sacredness of the water source, (c) the features of the waters at the foot of the mountains. The folklore found consisted of (a) Dewi Singowati, (b) magical gamelan, and (c) wild boar hunters. The traditional ceremonies that were found were the slametan banyu ceremony and the village cleaning.

The folklore narrative found is a people's memory about the function and meaning of Sumberawan springs. The memory is recorded in oral tradition and literature. One of the beauties of folklore lies in the way people record memories and communicate them to the next generation in a hereditary manner. This is as expressed by Ratna [8] that literature, art, and culture in the form of oral form are treasures of national heritage that have been restored through generations for centuries and have an important role in character education for the daily life of the Indonesian people.

The focus in Toyomarto Village is related to the Sumberawan springs, which is a cultural asset that remains in the community. These cultural assets can be used as capital in the development of cultural tourism in Toyomarto Village. Therefore, it is necessary to create a strategy to change these findings to be useful for tourism development. 


\subsection{Toyomarto Village Folklore Based Tourism Branding}

Toyomarto Village has the potential to be developed as a tourism destination, more specifically as natural tourism and cultural tourism. The cool weather and natural resources are valuable assets. Another potential of the village is the tangible (physical) cultural assets.

In addition, Toyomarto Village has a number of requirements that are sufficient to be used as a tourism destination or tourism village. This village has assets, products, and tourism objects. The assets owned are natural resources and cultural assets, which can be develops into products with economic values. Attractions that can be developed are water sources, mountains, traditional ceremonies/cultural festivals. According to Yanto [9] in his research on Gunung Kawi, Malang city, people tour because they are interested in folklore. People come for religious tourism. In addition, thousands of people attended cultural festival every year.

Branding comes from the word brand, and has a function as a differentiator or comparison with other brands [10]. Meanwhile, branding is an effort to communicate the brand to the public as a characteristic. Branding is very important so that the brand is immediately recognized, desirable, liked, so that the public is interested in consuming it. Branding efforts are critical to success in marketing. For example, one of the branding of Indonesian tourism abroad is the logo and slogan Wonderful Indonesia, while for domestic tourism is Pesona Indonesia [10].

The branding patterns that can be applied in Toyomarto Village by reconstructing folklore include (1) reconstructing folklore in the form of folklore into comics/pictorial stories, (2) reconstructing myths and legends into icons (3) reconstructing traditional ceremonial folklores into cultural festivals. The following is a description of the branding strategy.

\subsubsection{Branding through Comics}

Tourism branding can be done by reconstructing folklore in the form of legends or folklore into comics or pictorial stories. This is done as an effort to communicate the historical and literary aspects of tourism places. The reconstruction of folklore narratives in the form of comics and pictorial stories can be used as tourism support products.

The short comics and illustrated stories can be attached to accessories or t-shirts as tourism support products. Meanwhile, as a promotional effort, these comics can be published through social media. Reconstruction from folklore to comics can be done in the form of comic strips or short comics. Here are some examples of the reconstruction that have been carried out from folklore to comics.

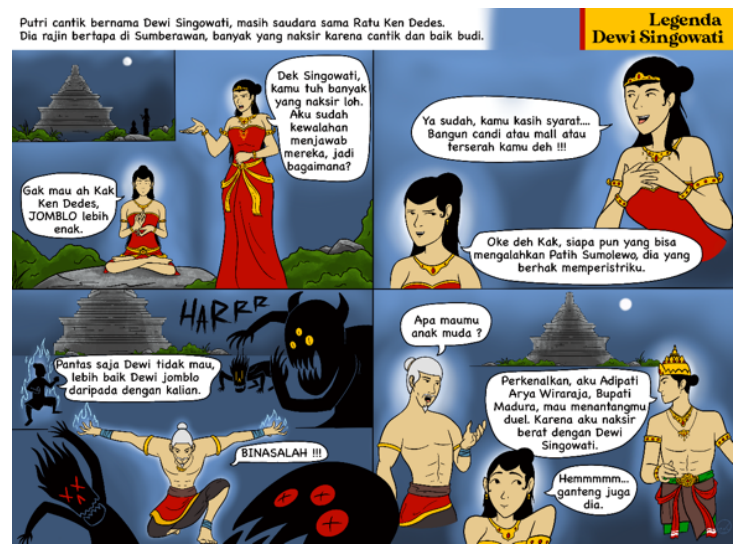

Fig. 1. The legendary Dewi Singowati Comic. 
Figure 1 is a visualization of folklore made in this study. Figure 1 is a folklore about the legend of Dewi Singowati. She is the sister of Ken Dedes, queen of Singhasari Kingdom in the 12th century. The comic tells that Dewi Singawati often meditated at the Sumberawan temple. Many men proposed her. Among of them are spirits and ghosts. But Dewi Singawati refused by arguing. Whoever wins against Patih Sumolewo, he will win. All of the lost the fight. Then came a handsome man from the Madura kingdom to challenge.

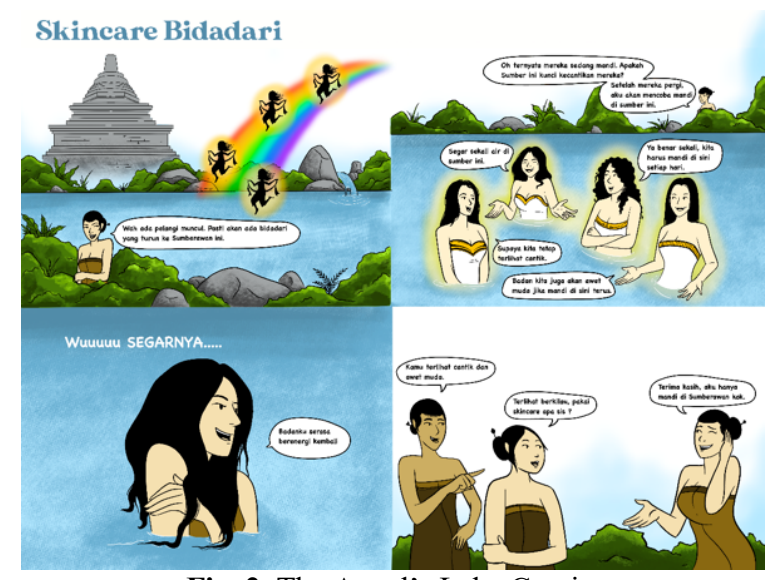

Fig. 2. The Angel's Lake Comic.

Figure 2 is a visualization of the folklore made in this study. Figure 2 is about myth. The myth tells that the angels came down to Sumberawan to swim. They came when the rainbow appeared. The angels are very beautiful. Their beauty secret is using holy water in the Sumberawan spring. The water in Sumberawan has the magic. Then people came to swim like those angels.

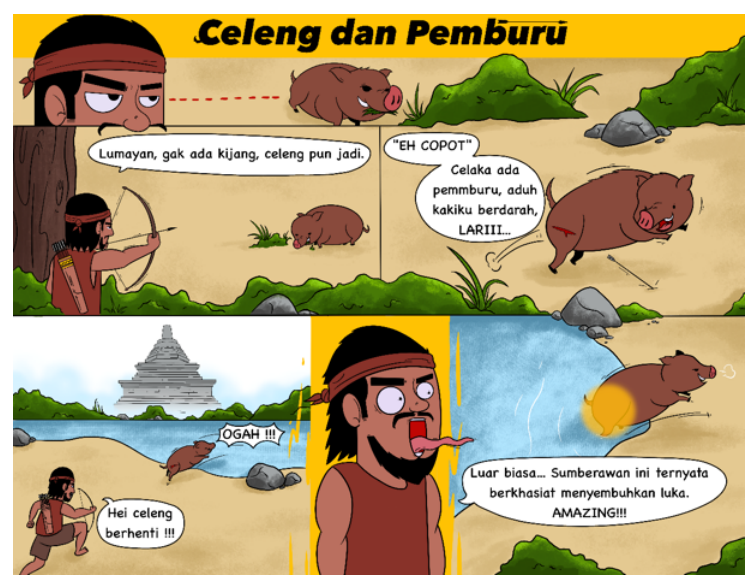

Fig. 3. Boar and Hunter's Comic.

Figure 3 is a visualization of folklore made in this study. Figure 3 tells story about the properties of holy water and wild boar hunter. The hunter has shot the wild boar. The wounded 
boar ran his way into the water. After getting out of the water, the wound healed. It is the miracle of holy water of Sumberawan.

The reconstruction of oral literature from legends, folk tales, and myths is carried out as an effort to utilize oral literature for the benefit of tourism branding. Thus, there is a change in the construction of oral literature and also the conversion into a tourism commodity. This conversion is not always permanent, because folklore in the form of oral literature with old constructs still exists, lives and develops in society. In addition, the reconstruction of folklore into comics is also an effort to revive the spirit of folklore so that it is easier for the younger generation to catch.

The comic strip was deliberately chosen because of its short or concise nature. This type of comic is the type that is popular in today's digital era. Because of its compactness, it is easier to distribute via digital media. Likewise, the characters are funny and satirical, making this comic type popular for making memes. For this reason, this type of comic was chosen to make it more accessible to the young audience who were the target consumers of comics.

\subsubsection{Icon Branding}

Icons can become a brand which is a distinctive feature of Sumberawan. From the myths and legends in Sumberawan, one of the icons that can be used is the figure of Dewi Singowati. This icon can be communicated through making comics and cultural festivals.

The choice of the legendary and mythical figures of Dewi Singowati was based on the uniqueness of the Singosari character who is believed by the local community. Dewi Singowati was chosen because in mythology, she was related to Ken Dedes. Ken Dedes has become an icon in Malang, representing the icons in several Kingdom of Singhasari historic sites. In addition, Dewi Singowati has not become an icon elsewhere. The name Singowati is phonologically very close to the name Singosari District, which is close to the Sumberawan community. Moreover, in the Sumberawan area there is also Singowati punden.

The following image is a visualization of the icon of Dewi Singowati.

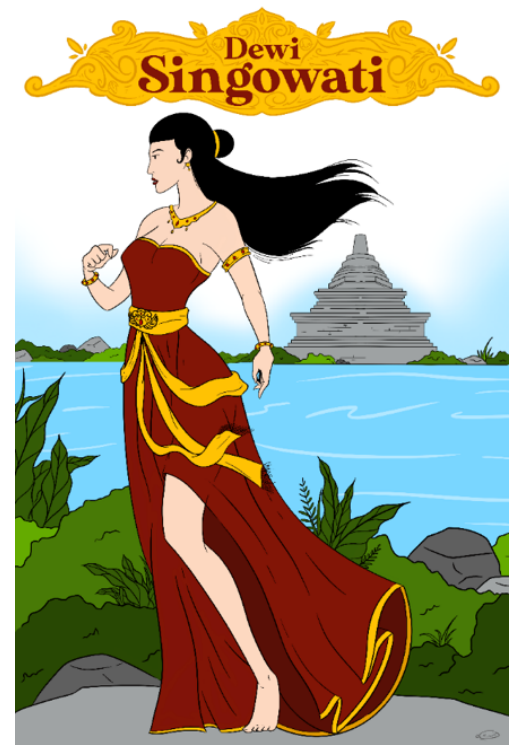

Fig. 4. Visualization of the Icon of Dewi Singowati. 
This icon visualization can be used for branding purposes. This can be transformed into a supporting product for cultural tourism. These products can be in the form of t-shirts, pins, key chains or other souvenirs with the icon of Dewi Singowati. Not only that, this icon can be transformed into a statue to be displayed at the entrance to the tourist area as a characteristic. Apart from being beautiful, this icon can also serve as a differentiator from other temple sites and water sources.

The transformation of a legendary figure into an icon can be an attempt to revive and create visuals of oral literature/folklore. Thus, reproducing legendary figures with visual features will make it easier for people to record their folk stories or legends in their subconscious memory. This is related to the importance of folklore functions in society. To concur with Titisari et al. [11], folklore such as legends and myths play a role in preserving the water sources in Sumberawan.

\subsubsection{Branding through Cultural Festivals}

Another branding strategy can be done through cultural festival activities. The cultural festival that has been carried out in Sumberawan is Selametan Banyu. This activity is routinely carried out by the community once a year by holding a tumpeng and sedekah bumi parade from the Toyomarto area to Sumberawan. The hamlets in Toyomarto Village participated in this cultural festival.

In fact, this cultural festival with arakan tumpeng dan sedekah bumi (the procession of tumpeng and earth alms) is enough to attract the attention of tourists. Given the very interesting attributes of the festival, each participant and village officials who take part in this festival use the attributes of customs. However, this festival is common in many villages in Java. Cultural festivals accompanied by general village cleaning are held in villages in Malang Regency every Sura (the first month of the Javanese calendar).

The last festival was held on August 30, 2020 with Tirta Amerta from Dusun Sumberawan to Candi Sumberawan. Even though during the pandemic, this was attended by five hundred people [12]. The following is a picture of Tirta Amerta's kirap kirap which ends with the selametan banyu ritual at Sumberawan Temple.

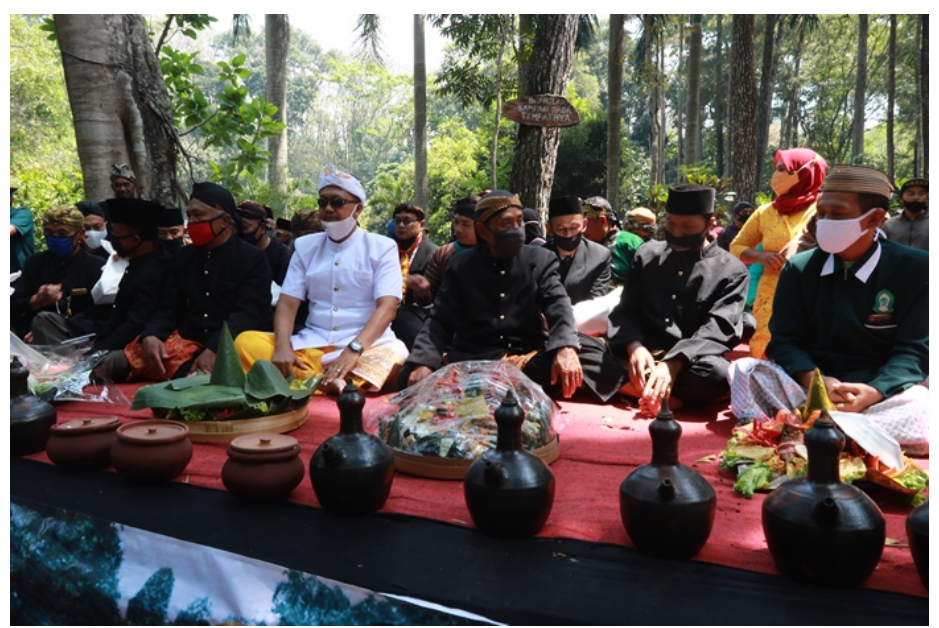

Fig. 5. Image Source: Radar Malang [12]. 
In order to attract more cultural tourism enthusiasts, the branding strategy with the Cultural Festival needs to be strengthened. Branding as an effort to communicate cultural tourism brands can be done by reconstructing traditional ceremonial folklore with cultural festivals that have more regional uniqueness. This feeling can be taken from oral literature at Sumberawan. This right is because oral literature is only owned by the Sumberawan community. Reconstruction can be carried out by taking the Sumberawan icon to be packaged into a cultural festival as the opening of the sacred traditional ceremony, namely Selametan Banyu.

The Sumberawan icon that can be used for packaging in the festival is the icon of Dewi Sigowati. Similar to Ken Dedes cultural festival which is the specialty of cultural festivals in Malang City, this can be a trademark of Sumberawan. Reflecting on the success of the Ken Dedes festival which was able to become a tourist branding for Malang City and bring in both domestic and foreign visitors, the Dewi Singowati festival as a Sumberawan icon can be fostered by various parties such as the local government and the local community.

\section{Conclusion}

Toyomarto Village has a lot of folklores. The folklores are related to the Sumberawan Springs. The findings of the variety of folklore in Toyomarto Village obtained from this study can complement the findings of previous research conducted by Titisari in 2016 in Toyomarto Village. In addition, it can also be concluded that folklore as a cultural asset can be used for the development of cultural tourism. The beauty and uniqueness of the people of Toyomarto Village in recording the meaning and sacredness of the springs, then communicating them to the next generation, can continue to be enlivened by transforming folk media into visual media as a tourism branding strategy.

\section{References}

[1] J. Vansina, Tradisi lisan sebagai sejarah. Penerbit Ombak, 2014.

[2] J. Danandjaja, Folklor Indonesia: ilmu gosip, dongeng, dan lain lain. Grafiti Pers, 1984.

[3] S. S. Hutomo, Mutiara yang terlupakan: Pengantar studi sastra lisan. Himpunan Sarjana Kesusastraan Indonesia, Komisariat Jawa Timur, 1991.

[4] S. Endraswara, "Metogologi Penelitian Folklor Konsep, Teori, dan Aplikasi Dilengkapi Dengan Cara Membuat Proposal dan Laporan Penelitian Folklor," Univ. Negeri Yogyakarta, 2009.

[5] W. J. Ong, Dari Lisan ke Aksara. Jakarta: Gramedia, 2013.

[6] C. Winick, “Anthropology's contributions to marketing,” J. Mark., vol. 25, no. 5, pp. 53-60, 1961.

[7] Purwadi, Folklor Jawa. Yogyakarta: Pura Pustaka, 2012.

[8] N. K. Ratna, Peranan karya sastra, seni, dan budaya dalam pendidikan karakter. Pustaka Pelajar, 2014.

[9] F. Yanto, “Gunung Kawi: Menengok Wisata Religi Dan Ritual Pesugihan,” J. Ilm. Sosiol. AGAMA, vol. 1, no. 2, pp. 20-56, 2018.

[10] G. Yuristiadhi and S. D. L. Sari, "Strategi Branding Pariwisata Indonesia Untuk Pemasaran Mancanegara," ETTISAL J. Commun., vol. 2, no. 2, pp. 31-41, 2017.

[11] E. Y. Titisari and L. D. Wulandari, "Sumber Air dalam Ruang Budaya Masyarakat Desa Toyomerto Singosari, Malang," RUANG J. Lingkung. Binaan (sp. J. Built Environ., vol. 5, no. 1, pp. 77-90, 2018.

[12] Hendarmono, "Bentuk Rasa Syukur, Geral Kirab Sakral di Sedah Bumi," Radar Malang, 2020. 